\title{
Nikomedya-311 Hoşgörü Fermanı ve Art Carnuntum Projesinin Kolektif Bellek Açısından Değerlendirilmesi
}

\author{
Zeynep Gamze MERT ${ }^{1 *}$, Filiz ERTÜRK²
}

\section{öz}

Kolektif bellek, toplumsal hatırlama araçlarından birisidir. Kolektif belleği yaşatmak için kültür ile sürekli bağlantılı tutmak gerekir. Düzenli olarak hatırlanması ve toplum içinde nesiller arasında öğrenilmesi gereklidir. Bu makalede İzmit kentinin tarihinde Roma İmparatorluğu'nda Nikomedya olarak başkentlik yaptığı dönemde MS. 311 yılında açıklanan "Hoşgörü Fermanı" ve bu fermanı hatırlamak amacıyla Viyana'da başlatılan ve İzmit'in de içinde olduğu 12 kenti kapsayan "Art Carnuntum" projesi incelenmiş ve kolektif bellek açısından değerlendirilmiştir. Makalede yöntem olarak, Art Carnuntum Projesi'nin İzmit ve Viyana temsilcileri ile görüşmeler yapılmış ve arşiv belgelerinden yararlanılmıştır. Ayrıca, Roma İmparatorluğu'nun bahsi geçen dönem ile ilgili literatür araştırması ve bu konuda çalışma yapan araştırmacı ile görüşme yapılmıştır. Elde edilen bulgular; projenin, yerel boyutta toplumun kolektif belleğini geliştirici önemli bir araç olduğunu, aynı zamanda evrensel boyutta, kentin tarihi ve kültürel zenginlikleri aracılığıyla tanıtımını ve dolayısıyla kalkınmasını destekleyecek potansiyele sahip olduğunu göstermektedir. Bu çalışmanın kolektif belleğin gelişimine ve kentin kalkınmasına katkı sağlaması beklenmektedir.

Anahtar Kelimeler: Kolektif Bellek, Nikomedya, Hoşgörü Fermanı, Art Carnuntum Projesi, Izmit.

\section{Evaluation of Nicomedia 311 Edict of Tolerance and Art Carnuntum Project in terms of Collective Memory}

\begin{abstract}
Collective memory is one of social remembering tools. Culture must constantly connect with collective memory to keep alive it. Generations should learn and remember their memory. This paper investgates "Edict of Tolerance" launched in 311 A.D. in Nicomedia when it was capital of Roman Imperior and Art Carnuntum Project started in Vienna including 12 cities to remember edict of tolerance. Art Carnuntum Project is evaluated in terms of collective memory. Interviews were made with there presentatives of Izmit and Vienna and their archieve documents were examined. Moreover, books, papers and documents about Roman Imperior were scanned and interviews were made with some researchers. Findings show Art Carnuntum Project is a crucial developer tool of collective memory at local scale. Moreover, the Project has a potential to promote social, economic and environmental developments through introduction of İzmit's historical and cultural richness at global scale. This paper will contribute to improve collective memory and city introduction.
\end{abstract}

Keywords: Collective memory, Nicomedia, Edict of Tolerance, Art Carnuntum Project, Izmit.

\footnotetext{
${ }^{1}$ Yrd. Doç. Dr., Kocaeli Üniversitesi, Mimarlık ve Tasarım Fakültesi, Mimarlık Bölümü, gamzemert@gmail.com

${ }^{2}$ Kocaeli Üniversitesi, Fen Bilimleri Enstitüsü, Mimarlık Anabilim Dalı, Doktora Öğrencisi

*ilgili yazar / Corresponding author: Zeynep Gamze MERT, gamzemert@gmail.com

Gönderim Tarihi: 26.10 .2016

Kabul Tarihi: 17.11.2016
} 


\section{GiRiş}

Yakın geçmiş için yeteri kadar bilgi vardır ancak geçmişe doğru gidildikçe bu bilgiler azalır. Daha da eski geçmiş için bir dizi bilgi bulunabilir ama toplumun üyeleri tarafından algılanmayabilir. Ancak bu durumu araştırmacıların fark etmemesi mümkün değildir. Bu durumda bellek toplumsal hatırlamanın en iyi araçlarından birisidir. Toplumsal hatırlamanın temelinde yer alan kolektif bellek sayesinde toplumlar geçmişleri ile ilişki kurar ve birbirlerine bağlanırlar.

Bazı olaylar vardır ki sadece gerçekleştikleri toplumun belleğinde değil, evrensel boyutta bir kolektif bellek ürünüdür. Bu bellek ürünlerinden bir tanesi de Roma İmparatorluğu'nun başkenti olan Nikomedya'da (bugünkü adıyla İzmit'te) yaşanmıştır. 30 Nisan 311 tarihinde Hristiyanlara ibadetlerini özgürce yapabilmelerine izin vermek üzere "Nikomedya 311-Hoşgörü Fermanı" yayınlanmıştır. Tüm Dünya için önemi büyük olan bu fermanın yerel halk tarafından bilinirliği yok denecek kadar azdır. Kolektif bellek hem geriye hem ileriye doğru iki yönde işler. Bellek sadece geçmişi kurgulamakla kalmaz, şimdi ve geleceğin deneyimlerini de organize eder. Bu nedenle kendi topraklarında gerçekleşen evrensel boyutta önem taşıyan bu bellek ürünü son derece önemlidir.

Bu makalede, İzmit'in yaklaşık 1700 yıl önce tanıklık ettiği "Nikomedya 311-Hoşgörü Fermanı" ile bu fermanı hatırlamak amacıyla Viyana'da başlatılan ve İzmit'in de içinde olduğu 12 kenti kapsayan Art Carnuntum Projesi incelenmiş ve kolektif bellek açısından değerlendirilmiştir.

Yöntem olarak, Art Carnuntum Projesi'nin 12 Nisan 2016 tarihinde İzmit temsilcisi Akın Ülkü Sevinç ve 14 Nisan 2016 tarihinde Viyana temsilcisi Piero Bordin ile görüşmeler yapılmış ve arşiv belgelerinden yararlanıımıştır. Ayrıca, Roma İmparatorluğu'nun bahsi geçen dönem ile ilgili literatür araştırılmış ve bu konuda çalışma yapan araştırmacı Radi Dikici ile 15 Nisan 2016 tarihinde elektronik ortamda görüşmeler yapılmıştır.

$\mathrm{Bu}$ çalışmanın kolektif belleğin gelişimine ve kentin kalkınmasına katkı sağlaması beklenmektedir.

\section{BELLEK VE KOLEKTIF BELLEK}

Bellek kavramı, çeşitli disiplinler tarafından ele alınmakta ve tanımlanmaktadır. Türk Dil Kurumu'nun Bilim ve Sanat terimleri başlığı altında bellek, Ruh Bilim Terimleri Sözlüğü'nde; "Yaşantıları, öğrenilen konuları, bunların geçmişle ilişkisinin bilincinde olarak anlıkta saklama gücü" olarak, Toplum Bilim Terimleri Sözlüğü'nde; "Insanın toplumsal bir varlık olmasını sağlayan, çevresi ile etkileşmesinin sonuçlarını anlığında saklayabilmesi ve daha sonraki etkinlikleri sırasında bu sonuçları anımsayabilmesi yeteneği” olarak açıklanmaktadır. Felsefe Terimleri Sözlüğü'nde ise iki açıdan ele alınmakta, "İlenimleri, algıları vb. saklama ve yeniden bilinçte canlandırma yetisi" ile "İzlenimlerin, algıların vb. saklandığı yer" olarak ifade edilmektedir(URL-1).

Huyssen belleği, algı, deneyim ile hayal edilenlerin birleşimi ve şimdiki zaman ile geçmişe dair imgelerin, kişinin imgelemesi sonucunda zihinde canlanması olarak tarif etmektedir (Huyssen, 1995, s. 35). Freud bellek üzerine çalışan önemli isimlerdendir ancak belleği bireysel türü üzerinden yorumlamaktadır. Kültürel ve toplumsal araştırmalarda kolektif bellek üzerinden gitmek daha doğru olacaktır (Coşkun, 2013, s. 20). Freud ile aynı dönemlerde bellek üzerine çalışan Henri Bergson'un öğrencisi 
Halbwachs ise önceki tanımlamalar üzerinden giderek 1920 'li yıllarda kolektif bellek kavramını ortaya koymuştur. Halbwachs'a göre bellek ve hatırlamanın öznesi her ne kadar birey olsa da onlar anılarını kurgulayan sosyal çerçeveye bağımlıdır. İnsan sadece iletişim içinde olduğu ortak belleğin çerçevesi içine yerleştirebildiği şeyleri hatırlar. Bu yüzden bellek, toplum tarafından üretilen kolektif bir oluşumdur ve dolayısıyla bu oluşum 'kolektif bellek' olarak adlandırılmalıdır (Çalak, 2012, s. 34-47). Halbwachs, bireysel belleğin bireyin içinde bulunduğu sosyal ve fiziksel çevre olmaksızın tariflenemeyeceğini ve her şekilde toplumsal, kolektif bir üretim olduğunu ifade etmektedir. Toplumsal bellek gruba içerden bakıp geçmişinin görüntüsünü tüm kademelerinde hatırlanabilir biçimde yansıtmayı hedefler ve derin değişimleri red eder. Öte yandan grup belleği kendi tarihinin farklılığını ve tüm diğer grup bellekleri karşısındaki özgünlüğünü vurgular (Assmann, 2001, s. 43-46). Bu nedenle döneme ait tarihsel süreci incelemek gerekir.

\section{TARIHHSL BAKIŞ}

\subsection{Roma Imparatorluğu ve Nikomedya M.S. 300’ler-Diocletian dönemi}

Büyük Roma İmparatorluğu hakkındaki ilk kayıtlar M.Ö.753 yılına dayanmaktadır. İmparatorluk M.S.31-235 yılları arasında 27 imparator tarafından yönetilmiştir. 235 yılından itibaren 284 yılına kadar geçen süre içinde tam bir kaos yaşanmış ve 51 kişi imparatorluk iddiasında bulunmuştur. 284 yılında İmparator Numerian Pers seferi sırasında hastalanarak Nikomedya (İzmit) civarında ölmüştür. Ülkedeki karmaşaya son vermek isteyen ordu, süvari birlikleri komutanı Diocletian'ı imparator ilan etmiş ve taç giyme töreni de 1 Nisan 284 tarihinde Nikomedya'da (İzmit) yapılmıştır. Böylece Büyük Roma İmparatorluğu'nun başkenti, 1037 yıl boyunca imparatorluğa başkentlik yapan Roma'dan Nikomedya'ya taşınmıştır (Dikici, 2013, s. 18). Kentin konumu, kuzey ve batı sınırlarına ulaşım uygunluğu, kara ve deniz ulaşım olanaklarının güçlü olması Nikomedya'nın başkent olmasının etkenlerinden bazıları olmuştur (Foss, 2002, s.3-4).

Diocletian imparatorlukta son yirmi yılda yaşanan tüm karmaşalara tanıklık etmiş ve ilk olarak bir takım düzenlemeler yapmıştır. Öncelikle askeri komutanları yanından uzaklaştırmış ve onları ülkenin çeşitli bölgelerine dağıtmıştır. Askeri ve sivil otoriteyi birbirinden ayırmış ve mali sistemi düzenleyerek ekonomik yapıyı güçlendirmiştir. Dioclatian, en önemli düzenlemeyi yönetim şeklinde yapmıştır. Mevcut durumu değiştirerek imparatorluğu önce dört eyalete ayırarak tetrarşi (dörtlü yönetim) yönetimini uygulamaya başlamıştır. Bu dört eyalet; Galya Eyaleti, İtalya Eyaleti, Balkan Eyaleti ve Doğu Eyaleti'nden oluşmakta ve her bir eyalet de kendi içinde bölgelere ayrılmaktadır. Toplam 4 eyalet ve 12 bölgeden oluşan imparatorluk yönetim modeli Diocletian tarafından getirilen bir modeldir (Dikici, 2013, s. 24, Dikici, 2016, s.n.y). İmparatorluk ve tetrarşi yönetim sınırları Şekil 1 de gösterildiği gibidir. 


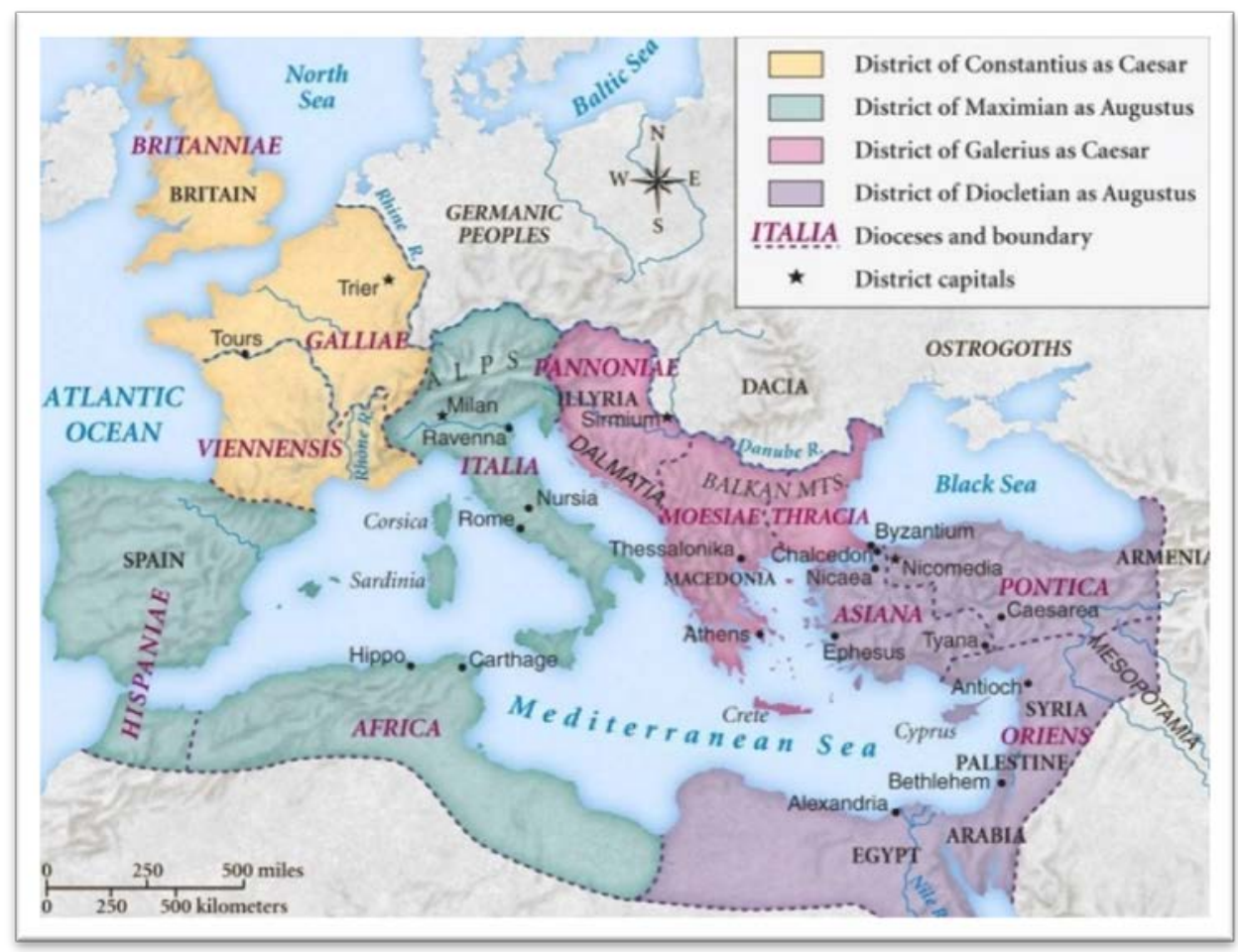

Şekil 1: M.S. 300'lü yıllar Roma İmparatorluğu Tetrarşi Yönetim Sınırları (https://en.wikipedia.org/wiki/Tetrarchy, Erişim Tarihi:12.04.2016)

1.Galya Eyaleti (Prefekture Galya): Bu eyaletin başkenti Trier olup, Cesar I. Konstantius Chlorus tarafından yönetilmektedir (Şekil 2). İki bölgeden oluşmaktadır ve bunlar; Britanya(İskoçya bölümü hariç) ve Fransa'dır.

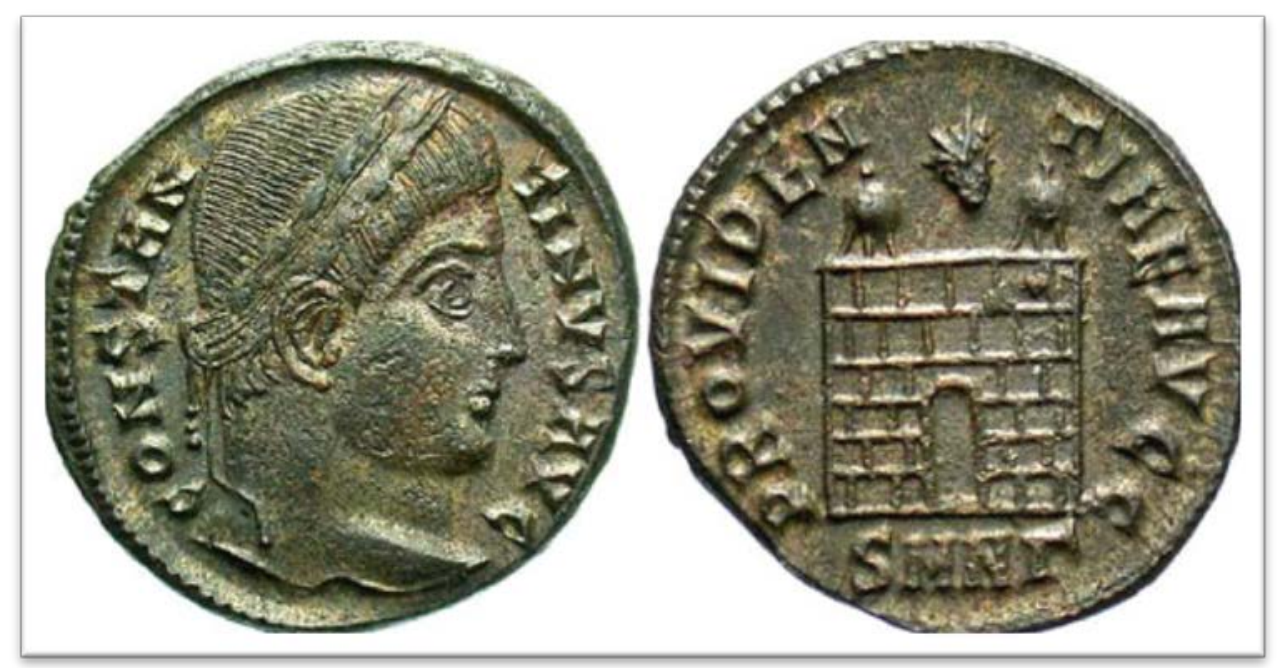

Şekil 2: 1.Konstantius Sikkeleri

(İzmit Art Nikomedya Derneği Arşivi, 2016, s.n.y.)

2. İtalya Eyaleti (Prefekture İtalia): Augustus Maximian tarafından yönetilmektedir (Şekil 3). Başkenti Milano olan bu eyalette üç bölge vardır. Bunlar; İtalya, İspanya ve Afrika(Fas ve Tunus'un kuzeyi)'dir. 


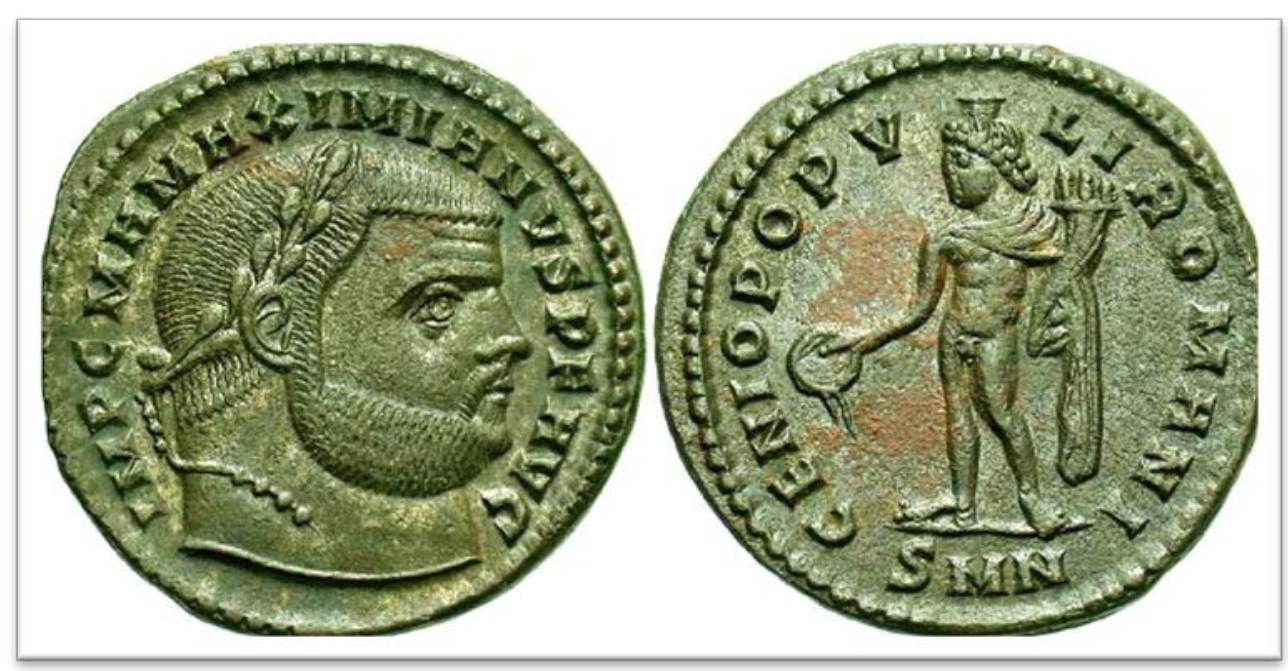

Şekil 3: Maximian Sikkeleri

(İzmit Art Nikomedya Derneği Arşivi, 2016, s.n.y.)

3. Balkan Eyaleti (Prefekture İllyricum): Ceasar Galerius tarafından yönetilen (Şekil 4) bu eyaletin başkenti Selanik olup Makedonya ve Yunanistan'la birlikte bazı Ege adalarını kapsar. Yugoslavya, Makedonya ile Yunanistan'ın kuzeyi, güneyi ve Mora Yarımadası olmak üzere üç bölgeden oluşur.

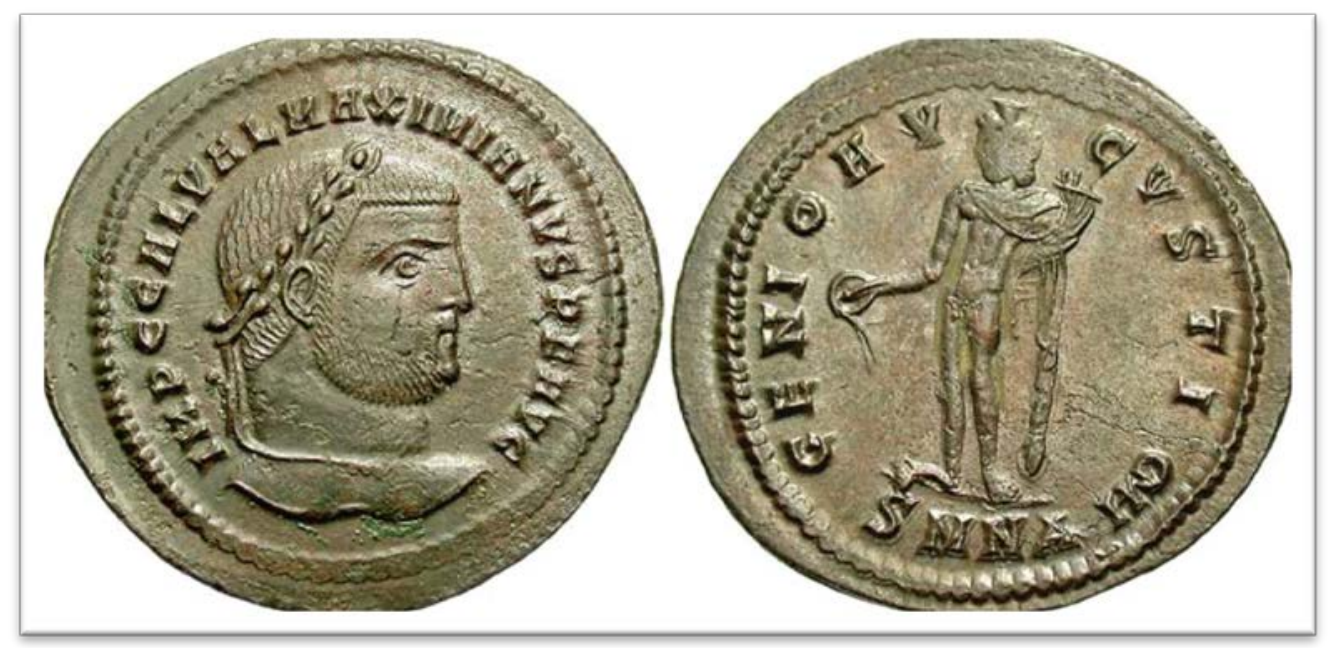

Şekil 4: Galerius Sikkeleri

(İzmit Art Nikomedya Derneği Arşivi, 2016, s.n.y.)

4. Doğu Eyaleti (Prefekture east): Başkent Nikomedya (İzmit) olan bu eyalet Diocletian tarafından yönetilmektedir (Şekil 5). Trakya, Anadolu, Doğu (Suriye, Lübnan, Ürdün, İsrail ve Sina Yarımadası) ve Mısır (Mısır'ın kuzeyi, Nil Vadisi ve Libya'nın kuzeyi) olmak üzere dört bölgeye ayrılır. 


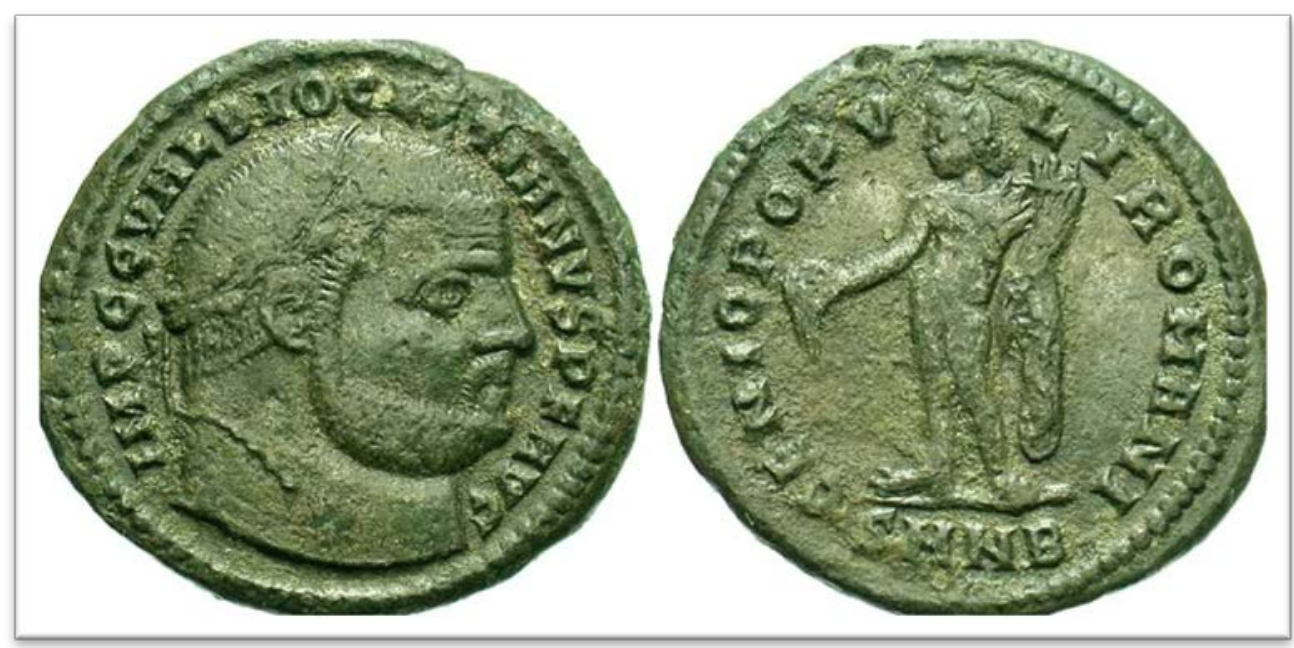

Sekil 5: Diocletian Sikkeleri

(İzmit Art Nikomedya Derneği Arşivi, 2016, s.n.y.)

Roma İmparatorluğu'nun tetrarşi yönetim şekli ile dört eyaletten oluşması ve her eyaletin ayrı imparator tarafından yönetilmesine rağmen bu durum esas olarak imparatorluğun dörde bölündüğü anlamını taşımamaktadır. İmparatorlar kendi eyaletlerinde sivil ve askeri yönetimin başıdırlar. Ancak zor şartlarda dört imparator birlikte hareket ederler. Bu oluşumda en üst otorite de Diocletian'dir. Tetrarşi yönetimi her zaman tehdit altında olan Roma İmparatorluğu'nun korunması ve yönetilmesi açısından son derece etkin bir yönetim modeli olmuştur (Dikici, 2013, s. 24-25, Dikici, 2016, s.n.y).

Diocletian Roma İmparatorluğu'nu Nikomedya (İzmit)'dan yönetmiştir. Kenti başkent olması sebebiyle Roma'ya benzer bir merkez yapmaya çalışmıştır. Yeniden yapılanma sürecinde dörtlü yönetimin temel intiyaçlarını karşılamak üzere öncelikle darphane ve silah imalathanesi kurulmuştur. Ayrıca konumundan dolayı askeri ve sivil ihtiyaçların üretildiği ve dağıtıldığı bir yer haline gelmiştir. Saray, sirk ve kamu binaları ile etkileyici bir başkent konumunda olan Nikomedya aynı zamanda eğitim ve diğer çeşitli aktivitelerin merkezi olmuştur (Foss, 2002, s.3-4).

Bu dönemde İmparatorluk bir düzene kavuşmuştur. Ancak Diocletian'ın çok tanrılı inanca sahip olması nedeniyle, Hristiyanlığa karşı sindirme politikaları uygulanmış ve halk bu yüzden cezalandırılmıştır. Birçok kilise yıkılmış, yakılmış ve Nikomedya'da başkent olarak bu döneme tanıklık etmiştir. Diocletian, imparatorluğunun son yıllarında Hristiyanlara karşı tavrını daha da artırmış, birçok tutuklama, işkence ve idam yaşanmıştır. Bir süre sağlık sorunları yaşayan Diocletian 305 yılında emekli olarak tahttan feragat etmiştir (Dikici, 2013, s. 29, Dikici, 2016, s.n.y).

\subsection{Hoşgörü Fermanları-30 Nisan 311 Nikomedya ve 13 Haziran 313 Milano}

Diocletian'ın ardından yerine geçen Galerius imparatorluk içindeki sorunları görüşmek üzere Tuna Nehri kıyısında bulunan Carnuntum'da 11 Kasım 308 tarihinde Diocletian'ın da katılığı bir toplantı düzenlemiştir. Toplantıda imparatorluk yeniden yapılandırılmış, doğuda Galerius ve Maximinus, batıda ise Licinius ve Constantine tarafından yönetilecek yeni bir tetrarşi düzeni oluşturulmuştur (Şekil 6). Tarihte 308-313 yılları arası bu imparatorlar "Carnuntum İmparatorları" olarak isimlendirilmiştir (URL-2). 


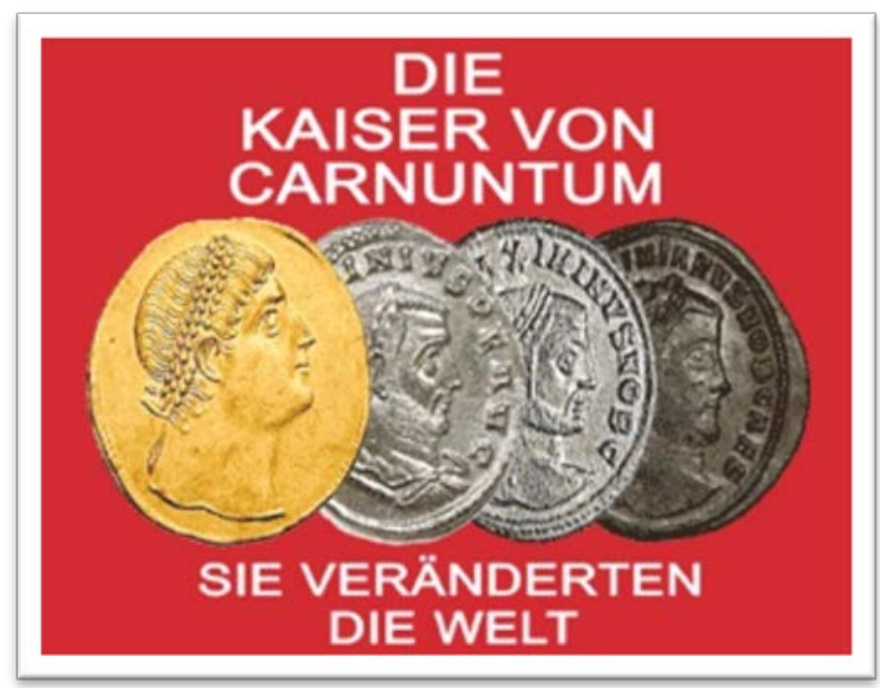

Şekil 6: 308-313 Carnuntum İmparatorları

(http://www.artcarnuntum.at/English.html, Erişim Tarihi:14.04.2016)

Bu süreç içerisinde diğer yandan katliamlar devam etmiş, ancak Hristiyanlık bu şiddet karşısında daha fazla yayılmıştır. Bunun üzerine Galerius 311 yılı Şubat ayında Sofya'da mevcut imparatorları toplantıya çağırmıştır. Görüşmeler sonunda Hristiyanlara karşı uygulanan şiddetin bir yarar getirmediği, hoşgörü ile davranılması gerektiğine karar verilmiştir. Böylece Hıristiyanlara devlet yönetiminde görev vermeden sadece ibadetlerini özgürce yapmaları için 30 Nisan 311 tarihinde Nikomedya (İzmit)'da "Hoşgörü Fermanı" yayınlanmıştır (Dikici, 2013, s. 35-36, Foss, 2002, s.5).

Nikomedya (İzmit) Hoşgörü Fermanı;

"Halkın iyiliği ve rahatığı için sağladığımız şeyler arasında, öncelikle Romalıların eski kanunları ve sosyal kurallarıyla her şeyi rahat bir duruma getirmeyi ve atalarının dini inançlarını benimseyen Hıristiyanlarında iyi bir duruma gelmelerini istedik. Çünkü herkes kendi kafasına ve isteğine göre kurallar koyduğu için, böyle bir ortamda insanlar atalarından ve köklerinden gelen inançları yaşayamadılar. Bu yüzden hayatları tehlike altındaydı ve birçok kez ölümle karşı karşıya kaldılar. Pek çoğu yine de kararlarında direndikleri için ve Hıristiyan tanrılarına hürmet edip tapmadıkları için ve biz herkese hoşgörüyle ve anlayışla yaklaşmak istediğimiz için düşündük ki herkese özgürlük sağlamalıyız. Bu sayede hem bir Hıristiyan olarak yaşamaya devam edebilirler hem de düzeni bozmadıkları sürece kendi dini toplantılarını yapabilirler. Mahkemelerin ne yapması gerektiğini bir başka bildiride anlatacağız. Bu hoşgörümüzden dolayı, kendi tanrılarına, bizim güvenliğimiz, ülkenin güvenliği ve kendi güvenlikleri için dua etmelidirler, böylece imparatorluk hiç bir taraftan darbe almaz ve onlar da evlerinde güven içinde yaşayabilirler." (Sevinç, t.y.,s.n.y) açıklamasını yapmaktadır.

Nikomedya Hoşgörü Fermanı'ndan iki yıl sonra Batı İmparatoru Constantine ve Doğu İmparatoru Licinius 13 Haziran 313 tarihinde, Nikomedya'da 30 Nisan 311 tarihinde yayınlanan "Hoşgörü Fermanı"nı genişleterek tüm dinlere özgürlük politikasını kabul eden "Milano Hoşgörü Fermanı'nı" ilan etmişlerdir.

\section{Milano Hoşgörü Fermanı;}

"Ben Constantine Augustus ve ben Licinius Augustus Milano'da karşılaşmamızda ve halkın iyiliği ve güvenliği için Tanrı'ya saygı göstermeyi içeren kanunların öncelik olarak düşünülmesi gerektiğini; ve topraklarımızda himayemiz altında yaşayan tüm 
Hıristiyanların ve diğer dinlere (ki her Tanrısal din cennetin koltuklarındadır ve farklılıklar nazikçe bertaraf edildiğinde hepsi çok cömert ve hayırlı olabilir)inanmayı tercih eden halkımıza ait olmasını düşündük. Ve böylece bütün bu doğru karşılıkları ve yararlı nasihatleri şu şekilde düzenlemeye karar verdik; Hiç kimse kalbini Hıristiyan dininin uyumuna bırakma fırsatını gelişigüzel reddetmemeli; kendi için en iyi olanı böylece kalplerine teslim olan Ulu Tanrı'yı düşünmeli ve olağan yaptığı her iyilik ve cömertlikte bunu göstermelidir. Bu nedenle ilahi dininiz; Hıristiyanları ilgilendiren ve sizlere daha önce resmi olarak verilen gelişigüzel kanunları ve şartları ortadan kaldırmanın bizi memnun ettiğini; Hıristiyan dinini taciz edilmeden gözlemlemek isteyen herkesin bunu özgürce ve açıkça yapabileceğini bilmelidir. Biz; Hıristiyanlara verilen özgür ve sınırlandırılmamış dinsel ibadet fırsatların bütünüyle sizin endişelerinize uyabileceğini düşündük. Çağımızın barışı için diğer dinlerin açıkça ifşa edilmesi ve iyilikleri için yapılan ibadetlerin, göreneklerin özgürce yapılma hakkını ve herkesin kendini memnun edebilecek ibadet imkânına sahip olacağını ve bunların bizim tarafımızdan bahşedildiğini gördüğünüzde ilahi dininiz bunları bilecek. Bu düzenlemeler; bizim her hangi din ya da itibarın değerini düşürmediğimiz için yapıldı." (Sevinç, t.y.,s.n.y).

açıklamasını yapmaktadır. Yaklaşık 1700 yıl önce yayınlanan "Nikomedya ve Milano Hoşgörü Fermanları" sayesinde tüm dinler için inanç özgürlüğü sağlanmış ve bu dönem insanlık için önemli bir dönüm noktası olmuştur.

\section{ART CARNUNTUM PROJESI: IZMIT'TEN VIYANA'YA}

$\mathrm{Bu}$ önemli tarihi olay hem dünyada hem de kentlerde uzun süre göz ardı edilmiştir. Ancak 2008 yılında başlatılan Art Carnuntum Projesi kapsamında gündeme getirilmiştir.

14 Nisan 2016 tarihinde Art Carnuntum Projesi kurucusu ve yöneticisi olan Piero Bordin ile elektronik ortamda bir görüşme yapılmıştır. Buna göre; 308 yılında Carnuntum'da yapılan toplantının anılması amacıyla 2008 yılında Art Carnuntum Projesi başlatılmıştır. Proje kapsamında, 311 Nikomedya ve 313 Milano Hoşgörü Fermanlarının 1700. yıldönümlerinde, açıklandıkları kentlerde, uluslararası katılımcılar ile birlikte bir seri etkinlik düzenlenmiştir. Avrupa'da 12 kentin proje ortağı olarak yer aldığı Art Carnuntum Projesi 2008 yılından itibaren Viyana yakınlarındaki Carnuntum (Petronell) kasabasından proje kurucusu ve yöneticisi olan Piero Bordin tarafından yürütülmektedir. Proje ortağı olan kentler; İzmit-Türkiye, Petronell-Avusturya, TrierAlmanya, Arles-Fransa, Zajecar-Sırbistan, Niş-Sırbistan, Milano-Italya, Roma-Italya, Selanik-Yunanistan, Sofya-Bulgaristan, Split-Hırvatistan, York-İngiltere'dir (Bordin, 2016, s.n.y., URL-3).

Proje kapsamında 11 Kasım 308 tarihinde Carnuntum'da yapılan toplantıyı anmak üzere 2008 yılında ilk etkinlik yine Carnuntum'da gerçekleşmiştir (Şekil 7). 30 Nisan 311 tarihli Nikomedya Hoşgörü Fermanı'nı anmak için 2011 yılında İzmit'te, 13 Haziran 313 tarihli Milano Hoşgörü Fermanı'nı anmak üzere Milano'da 2013 yılında uluslararası katılımcılarında yer aldığı sempozyumlar düzenlenmiştir. İzmit'te ve Avrupa'nın çeşitli kentlerinde uluslararası etkinlik ve projeler gerçekleştirilerek proje ortağı kentler arasında kültürel ve sanatsal işbirlikleri sağlanmaktadır. Avrupa'da 2010 yılından günümüze kadar 9 etkinlik, yerel ölçekte de 7 etkinlik gerçekleşmiştir (EK1).

İzmit Art Nikomedya Kültür Sanat Derneği Art Carnuntum Projesi'nin Türkiye'deki ortağı olup İzmit’te çalışmalarını sürdürmektedir. Koordinatörlüğünü dernek başkanı Akın Ülkü Sevinç'in yürüttüğü projenin amacı, günümüzden yaklaşık 1.700 yıl önce İzmit'ten 
dünyaya yayılan "HOŞGÖRÜ" kararını anmak, aradan geçen 17 yüzyıla rağmen kararın değerini çeşitli sanatsal ve kültürel etkinlikler düzenleyerek anlatmaktır.

İzmit Art Nikomedya Kültür Sanat Derneği kurucusu ve başkanı Akın Ülkü Sevinç ile 12 Nisan 2016 tarihinde dernek binasında proje hakkında bilgi almak üzere görüşme yapılmıştır. Bu görüşmeden; uluslararası proje koordinasyonunu yürüttükleri, Avrupa'da 11 proje ortağı olarak yer alan kentler arasında kültürel ve sanatsal etkinlikler düzenlendiği anlaşıımıştır. Ayrıca proje kapsamında gerçekleştirilen uluslararası etkinliklerle, yaklaşık 2300 yıllık aralıksız bir geçmişe sahip olan, birçok medeniyete ev sahipliği yapmış, özelikle başkentlik yaptığı dönemde Roma, İskenderiye ve Delphi den sonra dünyanın en büyük dördüncü metropolü olan kentimizin uluslararası tanıtımına pozitif bir katkı sağlandığı görülmektedir. Her yıl bu etkinliklerin düzenli olarak yapıldığı, derneğin yerel yönetim işbirliğini sağlayarak uluslararası yapılan etkinliklere katıımın sürekliliğini gerçekleştirdiği anlaşılmıştır. Hoşgörü Fermanının bu kentte açıklanması sebebiyle etkinliklere "Hoşgörü Kenti İzmit Etkinlikleri" adı verilmiş, bu sayede kentin hem yurt içi hem de yurt dışında tanıtımını sağlamak amacıyla İzmit Tarihi Turistik Yerler Kılavuzu ve İzmit Kent Tanıtım Filmi çalışmaları yapılmıştır (Sevinç, 2016.,s.n.y).

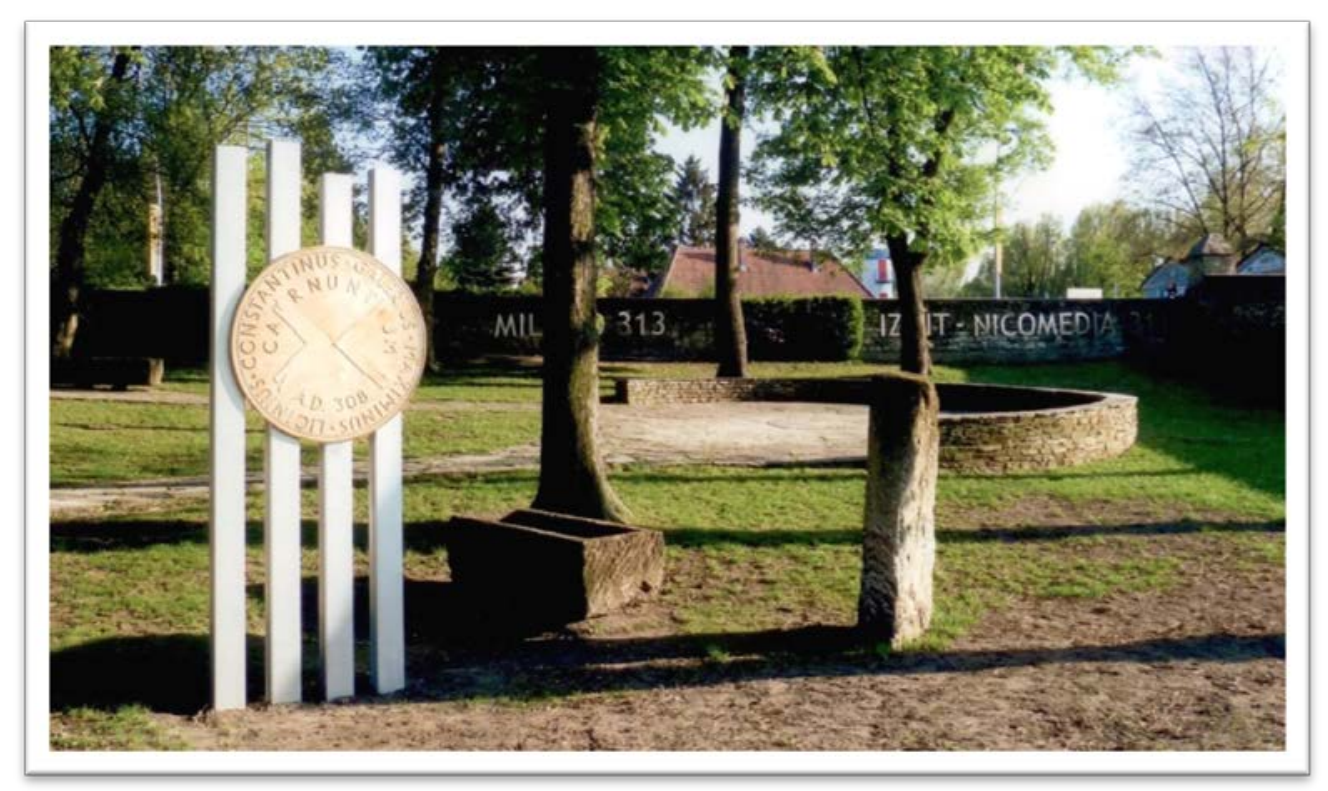

Şekil 7: Carnuntum (Petronell) Hoşgörü Anıtı (İzmit Art Nikomedya Derneği Arşivi, 2016, s.n.y.) 


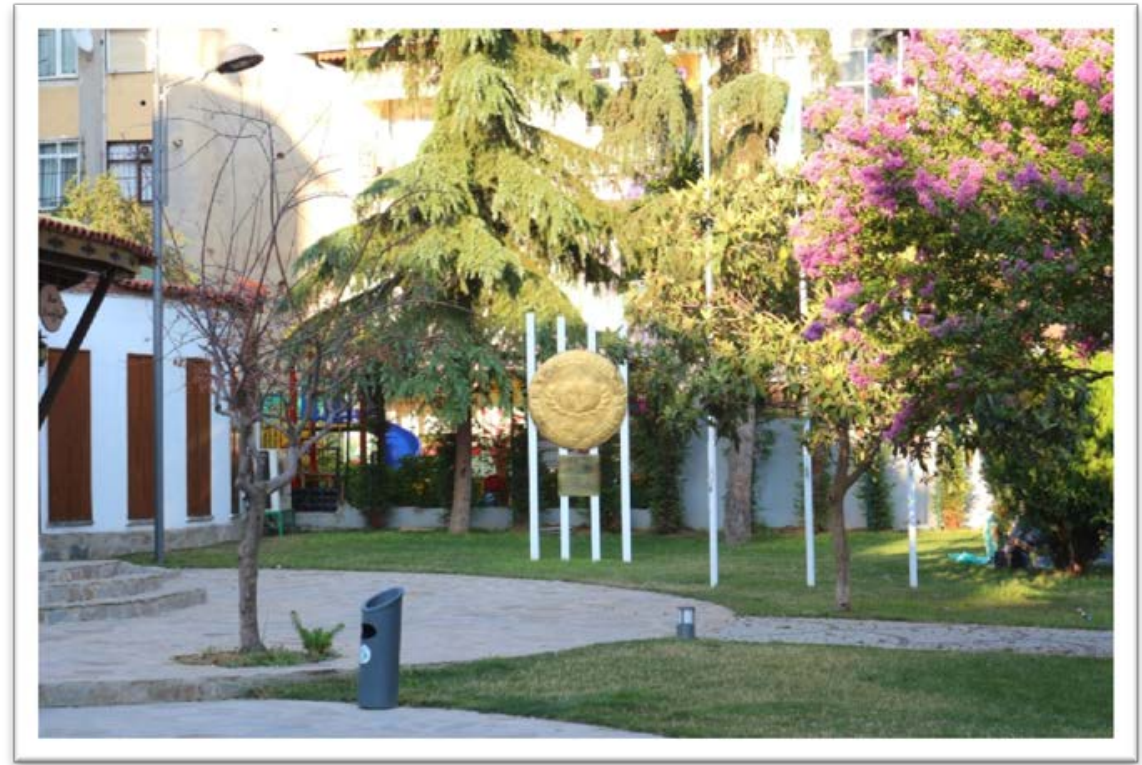

Şekil 8: İzmit (Nikomedya) Hoşgörü Anıtı

(İzmit Art Nikomedya Derneği Arşivi, 2016, s.n.y.)

Ayrıca proje kapsamında İzmit Belediyesi tarafından düzenlenen "Pişmaniye ve Hoşgörü Festivali" adı altında Temmuz 2011'de Cumhuriyet Parkı içerisinde İzmit Hoşgörü Anıtı'nın açılışı gerçekleştirilmiştir (Şekil 8). Etkinlik kapsamında kültür turları, paneller, konserler ve çeşitli sergiler düzenlenmiştir. Ayrıca ülkemize gelen yabancı misafirlere "Hemşehrilik Beratı ve Hoşgörü Fermanı" verilmiştir. İzmit Art Nikomedya Derneği, her yıl "Hoşgörü Kenti İzmit" adı altında çeşitli etkinlikler düzenlemeye devam etmektedir.

\section{BULGULAR}

Art Carnuntum Projesi kapsamında, 2008 yılından itibaren yurt içi ve yurt dışında bir dizi etkinlik düzenlenmektedir. Ek 1 de yer alan bu etkinlikler sürekli ve periyodik aralıklarla gerçekleşmektedir. Yurt dışındakiler her yıl aynı tarihte farklı ülkelerde ve şehirlerde yapılmaktadır. Bu etkinlikler yurt içi ve yurt dışından çeşitli katılımcıların bir araya gelerek ortak bir platformda Nikomedya-311 Hoşgörü Fermanının tartışılmasına ve dolayısıyla evrensel boyutta yayılımına olanak sağlamaktadır.

Proje kapsamında düzenlenen çeşitli kültürel etkinlikler (festivaller, konserler,..) aracılığıyla farklı coğrafyalarda yaşayan aynı belleğe sahip insanların bir araya gelmesiyle kültürler arası iletişim meydana gelmektedir. Ayrıca uluslararası katılımlı konferanslar konuyu bilimsel platforma taşımakta, araştırma ve geliştirme sonuçlarının paylaşımını sağlamaktadır. Bunun yanında etkinliklerin "Hoşgörü Kenti İzmit" adı altında yapılması, İzmit kentinin "Hoşgörü Kenti" olarak tanımlanmasına imkan vermiştir.

Özetle; Art Carnuntum Projesi hakkında yapılan araştırma ve görüşmeler sonucu elde edilen verilerden 4 temel bulguya ulaşılmıştır:

- Etkinlikler aracılığıyla Nikomedya-311 Hoşgörü Fermanının bilinmesi ve yayılması artmaktadır.

- Farklı coğrafyalarda yaşayan aynı belleğe sahip insanlar bir araya gelerek kültürel paylaşımlarda bulunmaktadır. 
- Nikomedya-311 Hoşgörü Fermanının akademik ortamda araştırılması sayesinde bellek hakkında daha çok bilgi ve belgeye ulaşılması sağlanmaktadır.

- "Hoşgörü Kenti İzmit” kente yeni bir kimlik ögesi olarak eklenmiştir.

\section{SONSÖZ}

Kolektif bellek, toplumsal hatırlama biçimlerinden birisidir. Kolektif belleği yaşatmak için kültür ile sürekli bağlantılı tutmak gerekir. Düzenli olarak hatırlanması ve toplum içinde nesiller arasında öğrenilmesi gereklidir. Bellek aracılığı ile hatırlanan doğa ile ilgili bilgi ve pratikler, geleneksel el sanatları, anılar, masallar, hikayeler, gösteri sanatları, sosyal pratikler, ritüeller, festivaller, etkinlikler, nesilden nesle aktarılır. Bu makalede İzmit kentinin tarihinde Roma İmparatorluğu'nda Nikomedya olarak başkentlik yaptığı dönemde MS. 311 yılında açıklanan "HOŞGÖRÜ FERMANI" ve bu fermanı hatırlamak amacıyla Viyana'da başlatılan ve İzmit'in de içinde olduğu 12 kenti kapsayan "Art Carnuntum" projesi incelenmiştir. Bu proje ve kapsamında düzenlenen etkinliklerin, hem evrensel boyutta hem de yerel boyutta son derece önemli olduğu anlaşılmıştır.

Elde edilen bulgulardan; Art Carnuntum Projesi'nin, geçmişte yaşanan bu olayın, günümüzde hatırlanmasına yönelik düzenlenen etkinlikler aracılığıyla, yerel boyutta toplumun kolektif belleğini geliştiren, evrensel boyutta kentin tarihi ve kültürel zenginlikleri aracılığıyla tanıtımını ve dolayısıyla kalkınmasını destekleyen bir araç olduğu görülmüştür.

Art Carnuntum Projesinin etkinlikleri aracılığıyla Nikomedya-311 Hoşgörü Fermanının bilinmesi ve yayılması yerel boyutta kolektif belleğin güçlenmesini sağlayarak kentlinin yaşadığı kente aidiyet duygusunu artırmaktadır. Ayrıca "Hoşgörü Kenti İzmit" yeni bir kimlik ögesi olarak kentlide oluşan imgelenme ile kolektif belleğin sürekliliğini sağlamaktadır. Nikomedya-311 Hoşgörü Fermanının akademik ortamda araştııılması sayesinde bellek hakkında daha çok bilgi ve belgeye ulaşılmakta ve dolayısıyla bu durum evrensel boyutta kentin tanınırlığına imkan vermektedir. Farklı coğrafyalarda yaşayan aynı belleğe sahip insanların bir araya gelerek kültürel paylaşımlarda bulunması da kolektif belleğin bilinmesi, yayılması ve sürdürülmesi açısından hem yerel, hem evrensel boyutta katkı sağlamaktadır.

Ancak tüm bu çalışmaların sadece bir sivil toplum kuruluşu tarafından yürütülmesi yeterli değildir. Yerel ve ulusal kademeler tarafından kayıt altına alınacak çalışmalar yapılmak zorundadır. Böylece kuşaktan kuşağa aktarılan kolektif bellek sayesinde toplumun aidiyet ve devamlılık duygusu sağlanacaktır.

Ayrıca Nikomedya-311 Hoşgörü Fermanının kolektif bellekteki yerinin korunması ve sürdürülebilmesi için Birleşmiş Milletler Eğitim, Bilim ve Kültür Kurumu (UNESCO) tarafından Somut Olmayan Kültürel Miras kapsamına alınmasına yönelik çalışmalar yapılması gereklidir.

$\mathrm{Bu}$ çalışmanın, kentin sahip olduğu fakat unuttuğu Nikomedya-311 Hoşgörü Fermanı'nın hatırlanarak, gelecek nesillere iletmeyi kurgulayan kolektif belleğin gelişimine ve kentin tanıtımına katkı sağlaması beklenmektedir. 


\section{KAYNAKLAR}

Assmann, Jan, Kültürel Bellek, Eski Yüksek Kültürlerde Yazı, Hatırlama ve Politik Kimlik, 2. B., Çev: Ayşe Tekin, Ayrıntı Yayınevi, İstanbul, 2001.

Bordin, Piero, 14 Nisan 2016 tarihinde elektronik ortamda yapılan görüşme, Kocaeli, 2016.

Coşkun, Lale Seval Biltekin, Kamusal Mekân ve Kolektif Bellek Bağlamında İstasyon Binalarının Incelenmesi ve Hızıı Tren İstasyonlarına Dönüşümü, Yüksek Lisans Tezi, Gazi Üniversitesi, Fen Bilimleri Enstitüsü, Ankara, 2013.

Çalak, Işıl Ekin, "Kentsel Ve Kolektif Belleğin Sürekliliği Bağlamında Kamusal Mekânlar: ULAP Platz Örneği, Almanya", Tasarım+Kuram Dergisi, Der: Ahmet Zeki Turan, Mimar Sinan Güzel Sanatlar Üniversitesi, İstanbul, 2012, Cilt No:8, Sayı:13,s. 34-47.

Dikici, Radi, Bizans İmparatorluğu Tarihi, 8. B., Remzi Kitabevi, İstanbul, 2013.

Dikici, Radi, 15 Nisan 2016 tarihinde elektronik ortamda yapılan görüşme, Kocaeli, 2016.

Foss, Clive, Anadolu'daki Ortaçağ Kalelerinin Incelenmesi: Nikomedya, 1.B., Çev.: F. Yavuz Ulugün, Kocaeli Gazetecilik ve Yayın Aş., Kocaeli, 2002.

Huyssen, Andreas, TwilightMemories, Making Time in a Culture of Amnesia, Routledge, New York, 1995.

İzmit Art Nikomedya Derneği Arşivi, Erişim Tarihi: 14.04.2016, s.n.y.

Sevinç, Akın Ülkü (Çeviren), Milano 313 Hoşgörü Fermanı, İzmit Art Nikomedya Derneği Arşivi, t.y, s.n.y.

Sevinç, Akın Ülkü (Çeviren), Nikomedya 311 Hoşgörü Fermanı, İzmit Art Nikomedya Derneği Arşivi, t.y, s.n.y.

Sevinç, Akın Ülkü,12 Nisan 2016 tarihinde İzmit Art Nikomedya Kültür Sanat Derneği'nde yapılan görüşme, Kocaeli, 2016

URL-1:http://www.artcarnuntum.at/English.html, Erişim Tarihi:14.04.2016.

URL-2:http://www.artNikomedya.org.tr/index.php/70-tanitim-katagorisi/duyurular/93-artcarnuntum-proje- koordinasyonu.html, Erişim Tarihi:14.04.2016.

URL-3: http://tdk.gov.tr/index.php?option=com_bilimsanat\&view=bilimsanat\&katego riget =terim\&kelimeget=bellek\&hngget=md, Erişim Tarihi: 21.04.2016.

\section{EK 1}

Avrupa'da Yapılan Etkinlikler

-Uluslararası Carnuntum Sempozyumu / 28-30 Mayıs 2010 / Viyana 
-Silk Road Meets Amber Road Etkinlikleri / 28-30 Mayıs 2011 / Viyana

-St Patron's Day Etkinlikleri / 22-23 Eylül 2011 / Zajecar

-Uluslararası Carnuntum Sempozyumu / 10-13 Kasım 2011 / Viyana

-Nis City Festivities / 1-3 Haziran 2012 / Niş

-Ponte Milvio Events / 25-28 Ekim 2012 / Roma

-Uluslararası Carnuntum Sempozyumu / 9-11 Kasım 2012 / Viyana

-Uluslararası Carnuntum Sempozyumu / 8-12 Kasım 2013 / Viyana

-Uluslararası Carnuntum Sempozyumu / 6-8 Kasım 2015 / Viyana

İzmit'te Yapılan Etkinlikler

-Pişmaniye Ve Hoşgörü Festivali / 22-24Temmuz 2011 / İzmit

-Hoşgörü Kenti İzmit Etkinlikleri / 26-30 Nisan 2012 / İzmit

-Niş Üniversite Korosu Konserleri / 27-28Nisan 2012 / İzmit

-Hoşgörü Kenti İzmit Etkinlikleri / 27 Nisan - 6 Mayıs 2013 / İzmit

-Hoşgörü Kenti İzmit Etkinlikleri / 30 Nisan 2014 / İzmit

-Hoşgörü Kenti İzmit Etkinlikleri / 30 Nisan - 5 Mayıs 2015 / İzmit 